Animal Health Research Institute, Beni Suef.

\title{
BACTERIOLOGICAL STUDIES ON P. MULTOCIDA AND MANNHEIMIA HEMOLYTICA ISOLATED FROM CHICKENS, DUCKS AND TURKEYS IN BENI SUEF GOVERNORATE WITH SPECIAL IDENTIFICATION OF P. MULTOCIDA BY PCR ASSAY
}

(With 3 Tables and 2 Figures)

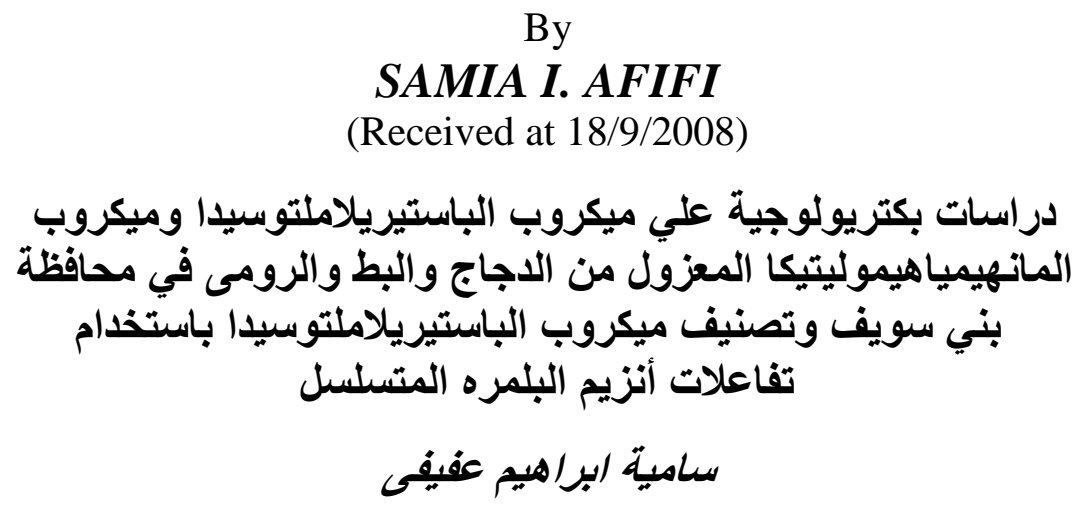

في در اسة مقارنة بين ميكروب المانهيميا هيموليتيكا وميكروب الباستيريلاملتوسيدا المسبيين

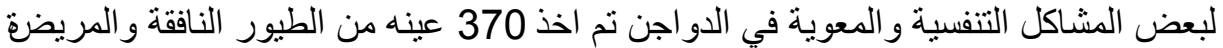
(الدجاج و البط و الرومى) و أجريت الفحوص البكتيريولوجية لهذه العينات حيث تم عزل 86 معزولة بكنيرية لميكروب الباستيريلاملتوسيدا 34 (121.25\%) منها وجدت في الدجاج و 38 و 34

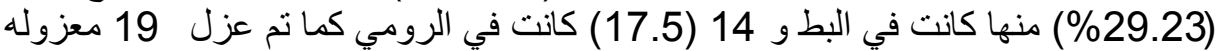

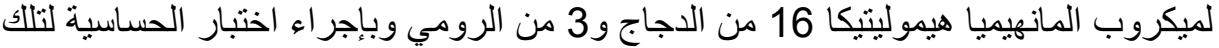

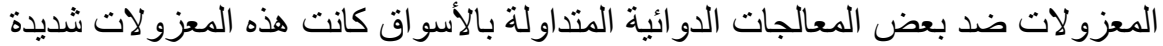

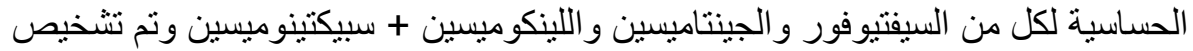
ميكروب الباستيريلاملتوسيدا باستخدام تفاعلات أنزيم البلمره المتسلسل وكانت نتائجه سريعه

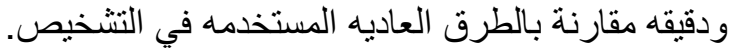

\section{SUMMARY}

Bacteriological examination of 370 samples which were taken from organs of freshly dead and diseased chickens, ducks and turkeys showing diarrhoea and respiratory disorders (collected from different farms at Beni Suef Governorate) revealed isolation of 34(21.25\%), $38(29.23 \%)$ and $14(17.50 \%)$ isolates of P. multocida respectively and 19 isolates of Mannheimia hemolytica of which 16(10\%) isolates from 
chickens and $3(3.75 \%)$ isolates from turkeys. The biological characters of both P. multocida and Mannheimia hemolytica isolates were discussed. PCR based technique was used in identification of $P$. multocida, all examined isolates gave a single amplified product of the expected size $460 \mathrm{bp}$.Antibiogram study showed that $P$. multocida and Mannheimia hemolytica isolated from chickens, ducks and turkeys were sensitive to ceftiofur, gentamycin, lincomycin + spectinomycin,and norfloxacin .The present study indicated that the recent development of species-specific PCR assay for $P$. multocida has provided rapid sensitive and specific method for identification of $P$. multocida isolated from chickens, ducks and turkeys.

Key words: P. multocida, Mannheimia hemolytica, chickens, ducks, turkeys

\section{INTRODUCTION}

P. multocida, the main causative organism of fowl cholera which is an acute septicemic disease of various domestic and wild birds was responsible for significant losses in poultry husbandry (Kardos and Kiss 2005), in addition Mannheimia hemolytica was isolated in pure cultures of samples from poultry with various pathological lesions including salpingitidis, peritonitis, pericarditis, hepatitis, enteritis, upper respiratory tract lesions and septicemia (Addo and Mohan 1985; Shaw et al., 1990; Suzuki et al., 1996). Woo and Kim (2006) isolated $P$. multocida from two outbreaks of fowl cholera in broiler breeder farms in Korea, Bojesen et al. (2007) isolated 75 Mannheimia hemolytica field isolates from Mexican chicken egg layers. In case of ducks, Gordan and Jordan (1982) reported that pasteurellosis is an important septicemic disease of growing ducklings whereas Edes et al. (1994) isolated Mannheimia hemolytica from the intestinal contents of Muscovy ducks suffering from enteritis. In turkeys Carpenter et al. (1989) stated that $P$. multocida was isolated from an outbreak of fowl cholera at a rate varied from 0 to $72 \%$ and Ibrahim and Sohair (2000) isolated Mannheimia hemolytica from turkeys diseased with infraorbital sinusitis. Until a short period of time identification and characterization of Pasteurella spp. have depended on their phenotypic characteristics such as morphology, biochemical and serological typing (Matsumato and Strain 1993), because of the antigenic complexity of $P$. multocida, serotyping was encountered by short falls involving the occurrence of either untypable isolates or those expressing multiple major somatic antigen (Rhoades and Rimler 1990). In recent years many workers showed that PCR based technique of $P$. multocida is a rapid technique with good discrimination 
and could be employed directly for routine typing of field isolates of $P$. multocida (Shivachandra et al., 2008). The present work was aimed to isolate P. multocida and Mannheimia hemolytica from chickens, ducks and turkeys farms with a history of diarrhoea, respiratory disorders and mortalities, identification of both microorganisms by conventional methods, identification of $P$. multocida by PCR assay and the in vetro sensitivity of the isolated bacteria to different chemotherapeutic agents.

\section{MATERIALS and METHODS}

\section{Samples:}

A total of 370 freshly dead and diseased birds (160 chickens from previous study, 130 ducks and 80 turkeys) showing diarrhoea, respiratory disoderes and mortalities were collected from different farms at Beni Suef Governorate .The birds were submitted to bacteriological examination.

\section{Isolation and identification:}

Isolation and identification of Pasteurella spp. was carried out according to Cruickshank et al. (1975), Collee et al. (1996) and Christensen et al. (2003).

\section{Animal pathogenicity:}

51 Swiss albino mice $15-20 \mathrm{~g}$ were divided into three groups: group one, 30 mice, were used for determination of the lethal activity of 15 isolates (chickens, ducks and turkeys isolates, 5 from each) of $P$. maltocida, group two, 16 mice, were used for determination of the lethal activity of 8 isolates of Mannheimia hemolytica (5 from chickens and 3 from turkeys), two mice were used for every isolate and group three, five mice, were used as control, the mice were kept under observation for 2 weeks before they were inoculated. Groups one and two were injected subcutaneously with $0.2 \mathrm{ml}$ of $10^{6}$ C.F.U of P. multocida or Mannheimia hemolytic obtained from diseased birds separately. Mice died within 24-72 h after injections were subjected to postmortem examination and reisolation of Pasteurella spp. was carried out from infected mice Cruickshank et al. (1975)

\section{Antibiogram of the isolated Pasteurella spp:}

The sensitivity of the isolated Pasteurella spp. to different antibacterial agents was done by disc diffusion method using dextrose starch agar medium according to Cruickshank et al. (1975) and Koneman et al. (1992) 


\section{Chemicals, reagents and buffers used in P.C.R studies of $P$. multocida:}

(Sambrook et al., 1989, Townsend et al., 1998)

\section{Reagents:}

Tris-HCL buffer, one mm EDTA, Tris EDTA buffer. SDS (sodium dodecyl sulfate) solution, proteinase K solution (Sigma), 5M $\mathrm{NaCL}$, buffer saturated phenol, chloroform / isoamyl alcohl (sigma), hexadecyle trimethyl ammonium bromide $10 \%$, sodium chloride 0.7, isopropanol (sigma), 70\% ethanol, Tris acetate EDTA (TAD) Electrophoreesis buffer (50xstock), ethedium bromide solution (stock solution), gel loading buffer

The primer used:

-Forward primer: Code KMTLsP 6 sequence 5,GCTGTAAACGAACTCGCCAC.3, -Reverse primer: Code KMTit7 5, ATCCGCTATTTACCEAGTGG3, obtained from MWG Biotech. AG, Berlin, Germany.

-Agarose gel (Sigma), chemical used in P.C.R reaction were shown in Table 1

Table 1: Chemicals used in P.C.R reaction

\begin{tabular}{|l|l|}
\hline \multicolumn{1}{|c|}{ Components } & Master mex \\
Content $(\mu \mathrm{l})$
\end{tabular}

Extraction of P. multocida genomic DNA: - (Ausubel et al., 1999)

Preparation of specific PCR reaction

-Specific PCR reaction of DNA from P. multocida was performed with some modification.

The reaction was carried out in a volume $50 \mu$ containing $10 \mu \mathrm{l}$ of genomic DNA solution.

-Specific PCR program and temprature profile: -

Amplification of DNA was performed by placing the tubes containing the reaction in a MI research thermal cycler programmed to fulfill 31 cycles. The temperature profile in the different cycles was: an initial denaturation cycle at $95^{\circ} \mathrm{C}$ for $4 \mathrm{~min}$, this was followed by 30 
cycles each comprising (1) denaturation step at $95^{\circ} \mathrm{C}$ for 1 min., (2) annealing step at $55^{\circ} \mathrm{C}$ for $1 \mathrm{~min}$, and (3) extension step at $72^{\circ} \mathrm{C}$ for 1 min. A final extension cycle at $72^{\circ} \mathrm{C}$ for 9 minutes was carried out.

- Electrophoreses of PCR products:

When the PCR program was terminated the PCR products were analyzed by electrophoretic separation in a $2 \%$ agarose gel containing ethedium bromide $(0.5 \mu \mathrm{g} / \mathrm{ml})$

With $1 \mathrm{x}$ buffer. Twelve $\mu \mathrm{l}$ of each PCR product were mixed with $3 \mu \mathrm{l}$ loading buffer and loaded into wells of the gell, the gel were run at 100 volt for 1 hour.

- Visualization and photography:

After electrophoreses the PCR patterns were visualized with U.V. and transilluminator the gels were photographed using Polariod camera.

- Six isolates of $P$. multocida isolated from chickens, ducks, and turkeys (2, isolates from each) showed high virulence to laboratory mice and strong biochemical reactions were used in PCR assay.

\section{RESULTS}

\section{Bacteriological examination}

Out of 370 samples from chickens, ducks, and turkeys, 105 isolates were recovered of which 19 isolates were Mannheimia hemolytica and 86 isolates were P. multocida (Table 2). Blood smear from the infected birds, stained with Leishman's stain, showed the bipolarity of the microorganisms (Fig.1).

Table 2: Incidence of both Mannheimia hemolytica and P. multocida in chickens, ducks and turkeys.

\begin{tabular}{|l|l|lr|lc|}
\hline Species & Number of samples & \multicolumn{2}{|c|}{ P. multocida } & \multicolumn{2}{|c|}{ Mannheimia hemolytica } \\
& & No & $\%$ & No & $\%$ \\
Chicken & 160 & 34 & 21.25 & 16 & 10 \\
Ducklings & 130 & 38 & 29.23 & 0 & 0 \\
Turkeys & 80 & 14 & 17.50 & 3 & 3.75 \\
\hline Total & 370 & 86 & 23.24 & 19 & 5.14 \\
\hline
\end{tabular}


Regarding to the biological properties of the isolates of Mannheimia hemolytica, they were Gram-negative, non-motile, rodshaped or pleomorphic with cells occurring singly and in pairs, colonies on bovine blood agar are mostly strongly B-hemolytic, urease, ornithine decarboxylase and Indole negative, oxidase and catalase positive ferment mannose, maltose, glucose, mannitol, glactose and grow on MacConcky agar, while. P. multocida isolates were Indol, catalase and oxidase positive, non hemolytic and ferment mannose, glucose, galactose and mannitol, all injected mice died within $72 \mathrm{~h}$ and showed typical lesions of Pasteurella spp.. The in vitro sensitivity of the isolates of Mannheimia hemolytica and $P$. multocida to different chemotherapeutic agents were indicated in table (Table 3)

Table 3: The in vitro sensitivity of the isolates of Mannheimia hemolytica and $P$. multocida to different chemotherapeutic agents.

\begin{tabular}{|c|c|c|c|c|c|c|c|c|c|c|c|c|c|c|c|}
\hline \multirow{4}{*}{$\begin{array}{c}\text { Chemotherapeutic } \\
\text { Agents }\end{array}$} & \multicolumn{9}{|c|}{ P. multocida } & \multicolumn{6}{|c|}{ Mannheimia hemolytica } \\
\hline & \multicolumn{3}{|c|}{ CH ICKEN (34) } & \multicolumn{3}{|c|}{ DUCKS (38) } & \multicolumn{3}{|c|}{ TURKEYS (14) } & \multicolumn{3}{|c|}{ CH ICKEN (16) } & \multicolumn{3}{|c|}{ TURKEYS (3) } \\
\hline & \multirow{2}{*}{$\mathrm{R}$} & \multicolumn{2}{|c|}{$S$} & \multirow{2}{*}{$\mathrm{R}$} & \multicolumn{2}{|c|}{ S } & \multirow{2}{*}{$\mathrm{R}$} & \multicolumn{2}{|c|}{ S } & \multirow{2}{*}{$\mathrm{R}$} & \multicolumn{2}{|c|}{$\mathrm{S}$} & \multirow{2}{*}{$\mathrm{R}$} & \multicolumn{2}{|c|}{$\mathrm{S}$} \\
\hline & & No. & $\%$ & & No. & $\%$ & & No. & $\%$ & & No. & $\%$ & & No. & $\%$ \\
\hline Ceftiofur $(30 \mu \mathrm{g})$ & 0 & 34 & 100 & 0 & 38 & 100 & 0 & 14 & 100 & 0 & 16 & 100 & 0 & 3 & 100 \\
\hline $\begin{array}{l}\text { Lincomycin }(15 \\
\mu \mathrm{g})+ \text { spectinomycin }(200 \\
\mu \mathrm{g})\end{array}$ & 9 & 25 & 73.53 & 4 & 34 & 89.47 & 3 & 11 & 78.57 & 4 & 12 & 75 & 1 & 2 & 66.66 \\
\hline Norfloxacin $(10 \mu \mathrm{g})$ & 24 & 10 & 29.41 & 8 & 30 & 78.95 & 2 & 12 & 85.71 & 11 & 5 & 31.25 & 1 & 2 & 66.66 \\
\hline $\begin{array}{l}\text { Choloramphenicol (30 } \\
\mu \mathrm{g})\end{array}$ & 31 & 3 & 8.82 & 28 & 10 & 26.32 & 10 & 4 & 28.57 & 12 & 4 & 25 & 2 & 1 & 33.33 \\
\hline Amoxicillin $(25 \mu \mathrm{g})$ & 34 & 0 & 0 & 34 & 4 & 10.53 & 14 & 0 & 0 & 16 & 0 & 0 & 3 & 0 & 0 \\
\hline Neomycin $(30 \mu \mathrm{g})$ & 34 & 0 & 0 & 38 & 0 & 0 & 14 & 0 & 0 & 16 & 0 & 0 & 3 & 0 & 0 \\
\hline Colisten sulphate $(10 \mu \mathrm{g})$ & 29 & 5 & 14.7 & 25 & 13 & 34.21 & 10 & 4 & 28.57 & 14 & 2 & 12.5 & 1 & 2 & 66.66 \\
\hline Gentamycin $(30 \mu \mathrm{g})$ & 4 & 30 & 88.23 & 0 & 38 & 100 & 14 & 0 & 100 & 3 & 13 & 81.2 & 0 & 3 & 100 \\
\hline Streptomycin $(10 \mu \mathrm{g})$ & 34 & 0 & 0 & 38 & 0 & 0 & 14 & 0 & 0 & 16 & 2 & 12.5 & 3 & 0 & 0 \\
\hline Doxycyclin $(30 \mu \mathrm{g})$ & 31 & 3 & 8.82 & 18 & 20 & 52.63 & 12 & 2 & 14.29 & 11 & 5 & 31.25 & 2 & 1 & 33.33 \\
\hline
\end{tabular}

$\mathrm{S}=$ sensitive $\quad \mathrm{R}=$ resistant

- The results of PCR based assay for moleculare detection of $P$. multocida using species-specific primer was shown in Fig. 2 


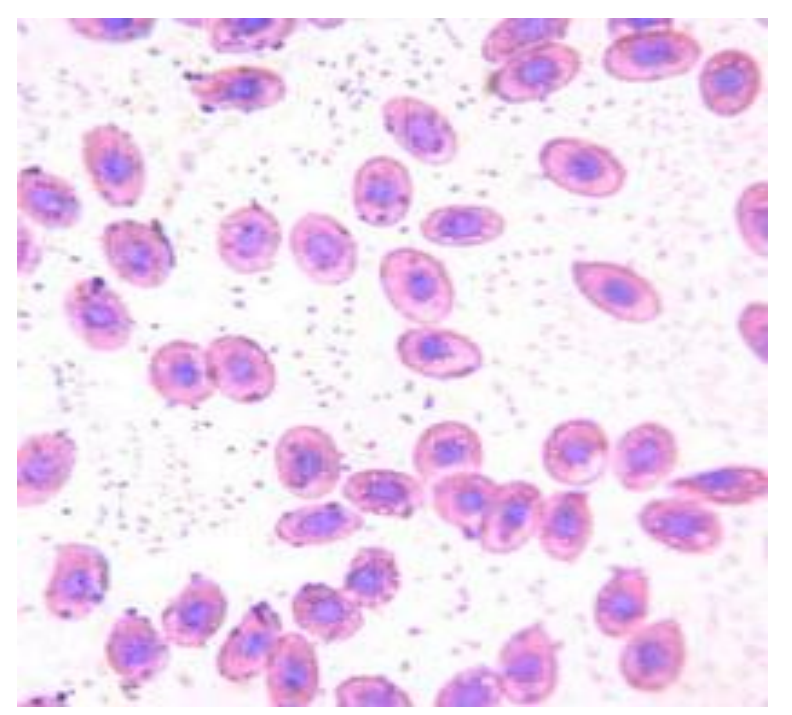

Fig. 1: Avian pasteurellosis. Blood smear (notice the bipolarity) Leishman's stain (1000)

$$
\begin{array}{lllllllll}
9 & 8 & 7 & 6 & 5 & 4 & 3 & 2 & 1
\end{array}
$$

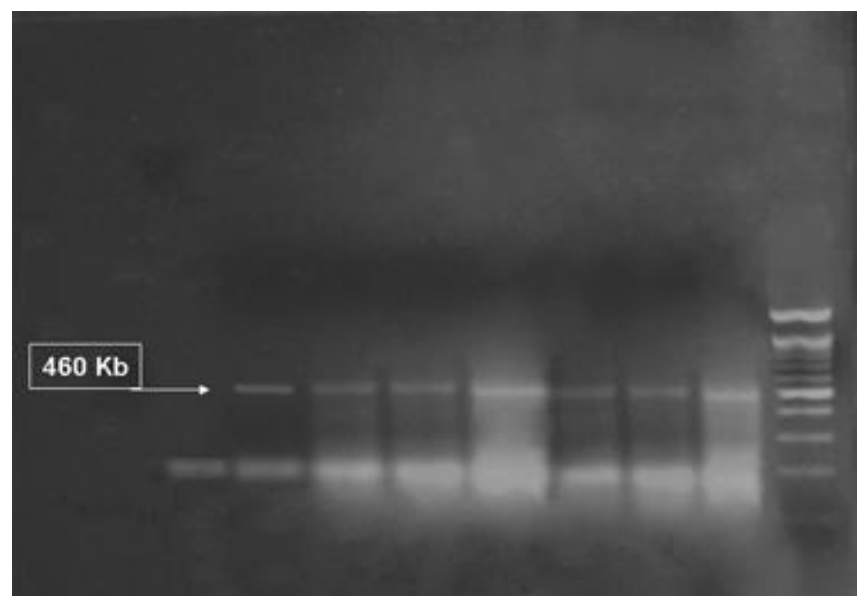

Fig. 2: Electrophoretic pattern of PCR production (460 bp specific for $P$. multocida) in $2 \%$ agarose gel stained with ethidium bromide.

Lane 1: DNA marker (100 bp) Lane 6

Lane 2

Lane 3

Lane 4

Lane 5

P. multocida ducks strains
Lane 6

Lane $8 \quad$ Control positive strain

Lane 9 Control nigative strain
P. multocida chickens strains $\quad$ Lane 7

$P$. multocida turkeys strains 


\section{DISCUSSION}

P. multocida and Mannheimia hemolytica can occur as commensales in the nasopharyngeal region and lower genital tract of apparently healthy birds and can be found as a primary or secondary pathogen in the disease process of poultry (Mirle et al., 1991; Tatum et al., 2005). In the present study P. multocida was isolated from dead and diseased chickens, ducks and turkeys at a rate of 21.25, 29.23 and $17.50 \%$ respectively, the high rate was found in ducks was similer to the results explained by Botzler et al. (1991) and Blanchong et al. (2006) who showed that the wetland and water facilitate the transmission of $P$. multocida to susceptible birds, beside that agreed with Radad and Fatma (2006) who isolated P. multocida from $25 \%$ of dead and diseased ducklings and Mbuthia et al. (2008) who isolated $P$. multocida from $25.9 \%$ of apparently healthy ducks. In chickens the results agreed with, Woo and Kim (2006) and in turckyes the results agreed with Carpenter et al. (1989). In case of Mannheimia hemolytica it was isolated from chickens, ducks and turkeys at rates of 10, 0 and $3.75 \%$ respectively, the results agreed with Byarugaba et al. (2007) who demonstrated that avian Mannheimia hemolytica isolates were pathogenic to chickens with only transit signs in turkeys and guineafowls. In chickens the results agreed with the results recorded by Lin et al. (1993) and Bojesen et al. (2003) who isolated Mannheimia hemolytica from normal and diseased chickens at different rates, in turkeys the results resemble the results recorded by Ibrahim and Sohair (2000) who isolated Mannheimia hemolytica from 4\% of diseased turkeys and in case of ducks the results agreed with the results recorded by Ibrahim and Sohair (2000) who failed in isolation of Mannheimia hemolytica from ducks and differed from the results recorded by Fouad and Hibat alla (2008) who isolated Mannheimia hemolytica from 4\% of diseased ducks. Regarding to the morphology, animal pathogenecity and biochemical characters of Mannheimia hemolytica and P. multocida, all injected mice died within $72 \mathrm{~h}$, the two organisms were Gram negative, bipolar rodes or coccobacilli, Mannheimia hemolytica were hemolytic, oxidase and catalase positive, indol negative ferment mannose, maltose, mannitole, glucose and galactose and grow well on MacConcky agar, these results agreed with Addo and Mohan (1985) Angen et al. (1999) Christensen et al. (2003) and Blackall et al. (2005). P. multocida differ from Mannheimia hemolytica in that it was non hemolytic on blood agar medium, didn't grow on Macconcky agar and indol positive these 
results agreed with Karaivanov (1984) and Collee et al. (1996). The in vitro sensitivity test showed that both Mannheimia hemolytica and $P$. multocida isolated from chickens were $100 \%$ sensitive to ceftiofur, from $81-88 \%$ were sensitive to gentamycin, $73-75 \%$ were sensitive to lincomycin + spectinomycin, from $29 \%$ to $31 \%$ were sensitive to norfloxacin and some isolates of Monnheimia hemolytica were sensitive to chloramphinicol and doxycycline while most isolates were resistant to colistin sulphate and streptomycin and all isolates were resistant to amoxicillin and neomycin this some what differ from Semjen et al., (1998) and Sarkozy et al. (2002) who showed that doxycyclin and norfloxacin respectively were highly effective against $P$. multocida and agreed with Yancey et al. (1987) who recorded that P. multocida and Mannheimia hemolytica from chickens were highly sensitive to ceftiofur and Lin et al. (2001) who showed that both Mannheimia hemolytica and $P$. multocida were sensitive to ceftiofur, amoxicillin, lincomycin and spectionomycin, moderately sensitive to tetracycline, enrofloxacin and slightly sensitive to chloramphenicol. P. multocida isolates recovered from ducks were highly sensitive to ceftiofur, gentamycin, lincomycin + spectinomycin and norfloxacin, from 26 to $50 \%$ of the isolates were sensitive to doxycycline, colisten sulphate and chloramphenicol, few isolates were sensitive to amoxicillin and all isolates were resistant to neomycin and streptomycin, this result nearly resemble the result recorded by Shaw et al. (1990), Takahashi et al. (1996) and Radad and Fatma (2006), in case of turkeys isolates of P. multocida, from 78 to $100 \%$ of them were sensitive to ceftiofur, gentamycin, lincomycin + spectinomycin and norfloxacin, $28 \%$ were sensitive to colisten sulphate and chloramphenicol and most of isolates were resistant to amoxicillin, doxycyclin, neomycin and streptomycin, this result agreed to some extent with the result recorded by Aye et al. (2001). Mannheimia hemolytica isolated from turkeys showed high sensitivity to ceftiofur, gentamycin, lincomycin + spectinomycin, norfloxacin and colisten sulphate, also moderatly sensitivite to doxycycline and chloramphenicol and all isolates were resistant to amoxicillin ,neomycin and streptomycin, Ibrahim and Sohair (2000) showed that Mannheimia hemolytica isolated from turkeys were sensitive to gentamycin, lincomycin + spectinomycin and norfloxacin. PCR assay for identification of P. multocida recovered from chickens, ducklings, and turkeys provided rapid, sensitive and specific method for identification of $P$. multocida. Fig 2 showed that all examined $P$. multocida isolates gave a single amplified product of the expected size of $460 \mathrm{bp}$ as 
recorded previously by Townsend et al. (1998) and Shivachandra et al. (2006). The figure clearing the sensitivity of PCR in identification of all examined $P$. multocida strains that consisted of chickens, ducks and turkeys strains $\{$ Lane (2-7) $\}$ as well as control positive reference vaccinal strain (Lane 8) and also clearing the specificity of the PCR assay in (Lane 9), the negative control DNA sample that didn't show any amplification products. The PCR assay enables confirmation of suspected colonies of $P$. multocida in few hours while identification of these colonies by conventional phenotypic methods requires up to five days. In conclusion bacteriological examination of 370 samples from freshly dead and diseased birds at Beni Suef Governorate revealed isolation of 86 (23.24\%) of P. multocida and 19(5.14\%) of Mannheimia hemolytica, identification of both microorganisms was done by conventional methods and the recent development of species-specific PCR assay has provided rapid, sensitive and specific method for identification of $P$. multocida.

\section{REFERENCES}

Addo, P.B. and Mohan, K. (1985): A typical P. hemolytica type A from Poultry. Avian Dis. 29 (1): $214-7$

Angen, O.; Mutters, R.; Cougant, D.A.; Olsen, J.E. and Bisgaard, M. (1999): Taxonomic relationships of the P. hemolytica complex as evaluated by DNA - DNA hybridization and 16S rRNA sequencing with proposal of Mannheimia hemolytica gen. nov., comb. nov., Mannnheimia granulomatis comb. nov., Monnheimia glucosida SP. nov., Mannheimia ruminalis - SP. nov. and mannheimia varigena SP. nov., Int. Sys. Bac. 49 Ptl: $67-86$.

Ausubel, F.M.; Brent, R.; ingston, R.E.; Moor, D.D.; Seidman, J.G.; Smith, J.A. and Struhl, K. (1999): Short protocols in Molecular Biology .Fourth Edition -current protocols is published by John Willy and Sons, Inc.

Aye, P.P.; Angrick, E.J.; Morishita, T.Y. and Harr, B.S. (2001): Prevalence and characteristics of Pasteurella multocida in commercial turkeys. Avian Dis. 45(1):182-90

Blackall, P.J.; Christensen, H.; Beckenham, T.; Blackall, L.L. and Bisgaard, M. (2005): Reclassification of P. gallinarum, Hemophilus paragallinarum, P. Avium and P. Volantium as Avibacterium gallinarum gen. nov, comb. nov., Avibacterium 
Paragallinarum - comb. nov., Avibacterium avium comb. nov., and Avibacterium Volantium - Comb. nov. Int Syst Evol. Mic. 55 (Ptl): $353-62$

Blanchong, J.A.; Samuel, M.D.; Goldberg, D.R.; Shadduck, D.J. and Lehr, M.A. (2006): Persistence of Pasteurella multocida in wetlands following avian cholera outbreaks.: J. Wild Dis. 42 (1): 33-9

Bojesen, A.M.; Nielsen, S.S. and Bisgaard, M. (2003): Prevalence and transmission of hemolytic Gallibacterium species in chicken production systems with - different biosecurity levels. Avian Pathol, 32 (5): 503- 10

Bojesen, A.M.; Vazquez, M.E.; Robles, F.; Gonzalez, C.; Soriano, E.V.; Olsen, J.E. and Christensen, H. (2007): Specific identification of Gallibacterium by a P.C.R using Primers targeting the $16 \mathrm{~s}$ r RNA and $23 \mathrm{~S}$ r RNA genes. Vet. Mic. 20; 123 (1-3): $262-8$

Botzler, R.G. (1991): Avian Cholera on orth coast California, distinctive epizootiological features Ann Ny. Acad. Sci 969: 224 - 228.

Byarugba, D.k.; Minga, U.M.; Gwakisa, P.S.; Katunguk, R.; Wakishaya, E.; Bisgaard, M. and Olsen, J.E. (2007): Virulence Characterization of Avibacterium Paragallinarum strains from Uganda. Avian Pathol 36 (1): 35-42

Carpenter, T.E.; Hirsh, D.C.; Kasten, R.W.; Hird, D.W.; Snipes, K.P.; McCapes, R.H. (1989): Pasteurella multocida recovered from live turkeys: prevalence and virulence in turkeys. Avian Dis. 33(1): 12-7.

Christensen, H.; Bisgaard, M.; BoJesen, A.M; Matters, R. and Olsen, J.E. (2003): Genetic relationships among avian isolates classified as $P$. haemolytica, Actinobcillus salpingitidis or $\mathrm{P}$. anatis with proposal of Gallibacterium anatis gen. nov. comb. nov and description of additional genomospecies within Gallibacterium gen. Nov. Int. J. syst. Evol. Mic. 53: 275 - 87

Collee, J.G.; Fraser, A.Ca.; Marmion, B.P. and Simmons, A. (1996): Practical medical microbiology. $14^{\text {th }}$ Ed. Charchill Livingstone. New-York, Edinbourgh London, Madrid Melbourne, Sanfrancisco and Tokyo.

Cruick-Shank, Duguid, J.P.; Marion, B.P. and Swain, R.H.A. (1975): Medical Microbiology. $12^{\text {th }}$ ed., Vol. II. Churchill Livingstone, Edinburgh, London and New-York. 
Edes, I.; Fodor, I. and Gglavits, R. (1994): Bacteriological characterization and pathological properties of $P$. hemolytica strains isolated from Muscovy duck. Magyar Allatorvo sok Lapja (49) 1: 23-26.

Fouad, I.A. and Hebat Alla A.E. Mohamed (2008): Bacteriological and pathological studies on $P$. hemolytica in ducks in Assiut Governorate Assiut Vet. Med. J. (54) 116: 220-230

Gordon, R. and Jordan, F. (1982): Poultry diseases $2^{\text {nd }}$ ed. Bailliere Trindall, London.

Ibrahim, R.S. and Sohair, Z. Hussein (2000): Bacterial agents associated with sinusitis in waterfowls and turckyes in Assiut an El-Minia Governorates Assiut Vet. Med. J. (44) 87: 185-195.

Karaivanov, L. (1984): Biochemical tests for identifying P. multocida. Vet. Med. Nauki 21 (9): 38 - 44.

Kardos, G. and Kiss, I. (2005): Molecular epidemiology investigation of outbreaks of fowl cholera in Geographical related poultry flocks. J. Clinic. Mic. Jan (43): 6. 2959-61

Konman, E.W.; Allen, S.D.; Jan, W.M.; Schrechn, Berrjer, P.C. and Winn,T.R. (1992): Colour atlas and textbook of diagnostic Microbiology $4^{\text {th }}$ ed. J. B. Lippicntt Co. Philadelphia U.S.A.

Lin, M.Y.; Cheng, M.C.; Huang, K.J. and Tsai, W.C. (1993): Classification, pathogenicity and drug susceptibility of hemolytic gram - negative bacteria isolated from sick or dead chickens. Avian Dis., 37 (1): 6 - 9.

Lin, M.Y.; Lin, K.J.; Lan, Y.C.; Liaw, M.F. and Tung, M.C. (2001): Pathogenicity and drug Susceptibility of the pasteurella anatis isolated in chickens in Taiwan. Avain Dis. 45 (3): 655 -8.

Matsumoto, M. and Strain, J.G. (1993): Pathogenicity of p. multocida. Its variable nature demonstrated by in vitro passage. Avian Dis., 37: 781-785

Mbuthia, P.G.; Njagi, L.W.; Nyaga, P.N.; Bebora, L.C.; Minga, U.; Kamundia, J. and Olsen, J.E. (2008): Pasteurella multocida in scavenging family chickens and ducks: carrier status, age susceptibility and transmission between species. Avian Pathol. 37(1): 51-7

Mirle, C.M.; Schongarth, H.; Meinhart, and Olm, U. (1991): Studies into incidence of $P$. hemolytica infections and their relevance to hens, with particular reference to disease of the egg-laying apparatus. Monatsh. Vet. Med. (46): 545-549. 
Radad, K. and Fatma, A. Moustafa (2006): Studies on P. multocida and other bacterial pathogens associated with some problems in duck farms in Assiut Goverorate Assiut Vet. Med. J. (52) 108: 336-353

Rhoades, K.R. and Rimler, R.B. (1990): Somatic serotypes of P. multocida strains isolated from avian hosts. Avian Dis., 31: 895-898.

Sambrook, J.; Fritsch, E.F. and Maniatis, T. (1989): Molecular Colng a laboratory Manual $2^{\text {th }}$ ed. Cxoldspring Habor Laboratory, coldspring Harbor, N.Y

Sarkozy, G.; Semjen, G.; laczay, P. and Horrath, E. (2002): Treatment of experimentally induced $P$. multocid infections in broilers and turkeys comparative studies of different oral treatment regimens. J., Vet. Med. B Infect. Dis. Vet. Puplic Health, 49 (3): $130-4$.

Semjen, G.; Magyar, T. and Laczay, P. (1998): Therapeutic effecancy of doxycycline against experimental $P$. multocida infection in broiler chickens. Acta Vet. Hung 46 (1): 85 - 93.

Shaw, D.P.; Cook, D.B.; Maheswaran, S.K.; Lindeman, C.J. and Holvorson, D.A. (1990): P. hemolytica as a Co-Pathogen in Pullets and laying hens. Avian Dis. 34(4): $1005-8$.

Shivachandra, S.B.; Kumar, A.A. and Chaudhuri, P. (2008): Molecular characterization of Avian strains of P.multocida serogroup-A:1 based on amplification of repetitive regions by PCR.Comp Imm. Micr. Infect Dis.31(1): 47-62.

Shivachandra, S.B.; Kumar, A.A.; Gautam, R.; Singh, V.P.; Saxena, M.K. and Srivastava, S.K. (2006): Identificatiuon of avian strains of P.multocida in India by conventional and PCR assays. Vet. J. 172 (3): 561-4.

Suzuki, T.; Ikedo, A.; Shimada, J.; Yanagawa, Y.; Nakazawa, M. and Sawada, T. (1996): Isolation of Actinobacillus salpingitidis, Avian $P$. hemolytica -like isolate from diseased chicken J. Jpn. Vet. Med. Assoc. (50): 85-88.

Takahashi, S.; Sato, H.; Yamada, T.; Takenouchi, T.; Sawada, T.; Nakano, K. and Saito, H. (1996): Outbreaks of fowl cholera inMuscovy ducks on a farm in Aomori prefecture. J. Vet. Med. Sci. 58: 269-272

Tatum, F.M.; Yersin, A.G. and Briggs, R.E. (2005): Constrution and virulence of $P$. multocida fhaB2 mutant in turkeys. Mic. Path. 39 (1-2): 9-17 
Townsend, K.M.; Frost, A. J.; Lee, C.W; Papadimitriou, J.M. and Daawkins, J.S. (1998): Development of PCR assays for species and type specific identification of $P$. multocida isolates. J. Cln. Micro., 36(4): 1096-205

Woo, Y.K. and Kim, J.H. (2006): Fowl Cholera outbreak in domestic poultry and epidemiological properties of $\mathrm{P}$. maltocida isolate. J. Mic. 44 (3): 344 - 53.

Yancey, R.J.; Kinney, M.L.; Roberts, B.J.; Good enough, K.R.; Hamel J.C. and Ford, C.W. (1987): Ceftiofur Sodium, a broadspectrum cephalosporin, evaluation in vitro and in vivo in mice. Am. J. Vet. Res. 48 (7): 1050 - 3. 